\title{
Farewell from the editor-in-chief: A short memoir
}

\author{
José Vinhas ${ }^{1}$ \\ ${ }^{1}$ Nephrology department, Centro Hospitalar de Setúbal, Setúbal, Portugal
}

For 6 years I have had the honor of being the Editor-in-Chief of The Portuguese Journal of Nephrology and Hypertension. This issue is the last under my editorship. Originally titled Revista Portuguesa de Nefrologia e Hipertensão, the Portuguese Journal of Nephrology and Hypertension will celebrate 36 years of publication next year.

The Portuguese Journal of Nephrology and Hypertension was conceived in 1986, and Fernando Carrera, who was the first Editor-in-Chief, was the Editor-in-Chief of the journal for 26 years. We are now entering the 36th year of the journal, and it is now a fully fledged publication that is indexed in both the Thompson Reuter's SciELO citation índex and the Directory of Open Access Journals (DOAJ).

In the 24 issues published during my tenure as Editor-in-Chief, we have published 339 articles, which included 16 commentaries, 7 editorials, 49 perspectives, 61 review articles, 72 original articles, 87 case reports, 24 nephropathology quizzes, 10 tubular quizzes, and 11 letters to the editor.

The journal's success is the result of a team effort. Since I became Editor-in-Chief, the time-consuming challenge of running the PJNH has been assisted for the first time by an Executive Editor (Dr. Ana Azevedo). Her unstinting support, together with her wit and committment, were crucial for the success of the journal. I am deeply grateful to her: to work closely with a person of such ability has been a huge honour. Without her, the journal wouldn't be the same.

Our committed Editorial Board, composed of Portuguese and internationally renowned editors as well as expert Editorial Board members, covered the broad spectrum of nephrology. Jointly, they were the essential core team for what has come to be a constructive peer-review system in our journal. I would like to take this opportunity to express my thanks to all editors. They were an essential element of the journal.

Our journal is an English-language publication, meaning that the English text editor is a critical component of the journal team. I would like to acknowledge, without reservation, the unfailing support of Ms. Rebecca Baker, the English text editor, over the long days of this ride.

With this issue, Professor José António Lopes takes over as Editor-in-Chief of the journal. I wish Professor Lopes the very best and fully expect that he will be an outstanding Editor-in-Chief of the PJNH.

\section{ORCID}

José Vinhas (iD) 0000-0002-1578-6515

Correspondence to:

Jose Vinhas, MD

E-mail: jose.m.vinhas@gmail.com

(C) 2021 Portuguese Journal of Nephrology \& Hypertension. Published by Publicações Ciência \& Vida This is an open access article under the CC BY-NC-ND license (http://creativecommons.org/licenses/by-nc-nd/4.0/). 